\title{
䂃床㖄究セミナー記録
}

日本臨床外科学会・日本外科学会共催（第 81 回日本臨床外科学会総会開催時）

第 23 回臨床研究セミナー

\begin{abstract}
「臨床研究の基礎と実践」によせて
日本外科学会臨床研究推進委員長, 岡山大学大学院医歯薬学総合研究科消化器外科学

藤原 俊義
\end{abstract}

(2019 年 11 月 16 日受付)

医療安全の観点から, 外科医を取り巻く社会情 勢が大きく変容する中, 患者に安全で有効な最善 の外科医療を提供するためには, 科学的かつ倫理 的な臨床研究によって示されるエビデンスを確立 することが最も重要である。良質なエビデンスを 集約した診療ガイドラインなどによって，さらに 安全な日々の外科医療は支えられており, 臨床研 究を適正に計画・実施・評価することが強く求め られてきている，本セミナーは，臨床研究に関す る基礎的な知識から実践的な応用例まで, 幅広い トピックスをタイムリーに組み込み, 日本外科学 会会員の先生方に臨床研究を確実に推進いただけ るよう企画されている.

第 23 回臨床研究セミナーは, 第 81 回日本臨床 外科学会総会 (花㟝和弘会長, 高知大学外科学講 座外科 1 教授）の最終日午後に開催された。「臨 床研究の基礎講座」では, 臨床研究の多変量回帰
分析において，適切な変数選択が必要であること を解説いただいた。また, 高知大学医学部附属病 院の次世代医療創造センターからは, Academic Research Organization（ARO）として医師主導 治験を支援されている実態を紹介いただいた。外 科臨床研究の実践」では, 昨年 1 月に米国臨床腫 瘍学会（ASCO-GI）にて報告され注目を集めた,

切除可能膵癌に対する術前化学療法の臨床研究の 結果を紹介いただき，また保険適用によって一層 の広がりを見せているロボット支援手術の臨床研 究論文をオーバービューいただいた。

ご講演賜った講師の先生方，また司会の労をお 取りいただいた臨床研究推進委員会委員の先生方 に深謝するとともに，さらなるご協力をお願いし たい

利益相反：なし

第 1 部 臨床研究の基礎講座

1. 査読者の立場から見た医学論文における統計解析の留意点

2. 臨床研究支援センターの役割一地方大学における医師主導治験の支援を中心に一

頭 政 光

第 2 部「若手外科医のための臨床研究助成」成果発表 (H28年度受賞) (抄録割愛)

1. オミックス解析を用いた癌エクソソームによるイレッサ耐性メカニズムの解明

子

2. 発光ダイオード（LED）の波長強度可変装置による肝細胞保護に関する研究

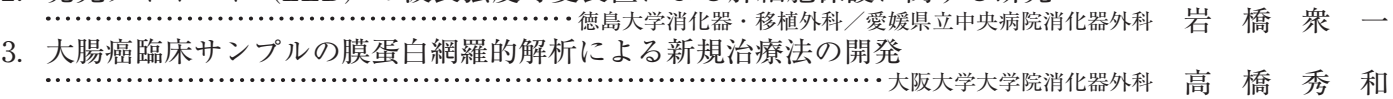

4. 抗 PD-1 抗体および化学療法の新規併用治療に向けた食道癌・胃癌における感受性予測研究

知

5. 肝発癌を促進する微小環境の制御による革新的癌治療法の開発・研究

第 3 部 外科臨床研究の実践

1. 切除可能膵癌に対する術前化学療法の臨床研究の経験から………東北大学消化器外科海 野 倫 明

2. ロボット手術の臨床研究〜胃癌, 直腸癌を中心に〜 ……高知大学医療学講座医療管理学分野 小林 道 也

\section{BASIC AND PRACTICAL METHODS FOR CLINICAL STUDY}

Toshiyoshi Fujiwara

Clinical Study Promotion Committee, Committee Chairperson, Department of Gastroenterological Surgery, Okayama

University Graduate School of Medicine, Dentistry, and Pharmaceutical Sciences, Okayama, Japan 